NASA Technical Memorandum 88833

\title{
Space Solar Cell Research: Problems and Potential
}

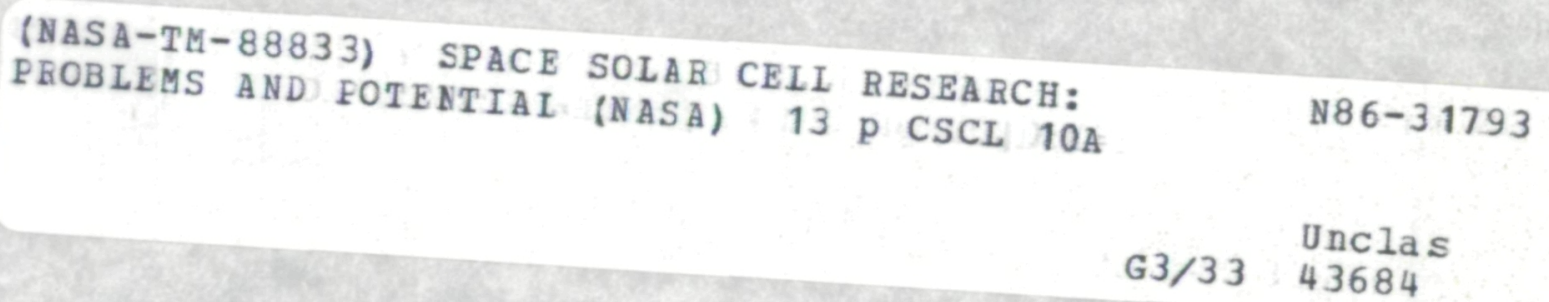

Dennis J. Flood

Lewis Research Center

Cleveland, Ohio

Prepared for the

Conference on Photovoltaics for Commercial Solar Power sponsored by the Society of Photo-Optical Instrumentation Engineers Cambridge, Massachusetts, September 15-19, 1986 


\author{
SPACE SOLAR CELL RESEARCH: PROBLEMS AND POTENTIAL \\ Dennis J. Flood \\ National Aeronautics and Space Administration \\ Lewts Research Center \\ Cleveland, Ohio 44135
}

\begin{abstract}
SUMMARY
The value of a passive, maintenance-free, renewable energy source was immediately recognized in the early days of the space program, and the stificon solar cell, despite its infancy, was quickly pressed into service. Efficiencies of those early space solar arrays were low, and lifetimes shorter than hoped for, but within a decade significant advances had been made in both areas. Better performance was achieved because of a variety of factors, ranging from improvements in silicon single crystal material, to better device designs, to a better understanding of the factors that affect the performance of a solar cell in space. Chief among the latter, particularly for the mid-tohigh altitude (HEO) and geosynchronous (GEO) orbits, are the effects of the naturally occurring particulate radiation environment. Although not as broadly important to the photovoltaic community at large as increased efficiency, the topic of radiation damage is critically important to use of solar cells in space, and is a major component of the NASA research program in space photovoltaics. This paper will give a brief overview of some of the opportunities and challenges for space photovoltaic applications, and will discuss some of the current research directed at achieving high efficiency and controlling the effects of radiation damage in space solar cells.
\end{abstract}

\title{
INTRODUCTION
}

The NASA space photovoltaics program has been designed to be responsive to key technology needs of future space missions across the entire NASA mission model (ref. 1). The anticipated energy requirements of future missions are illustrated in figure 1. Research and technology programs are in place that address the applicability of photovoltaic power systems to a wide range of power requirements, from hundreds of watts to mult thundred kilowatts, and to a variety of operating environments. Specific applicability to any given mission depends strongly on its exact nature, but there are certain system attributes for various mission subsets that serve to focus the R\&T program. Table I contains a breakout of some important mission subsets, their associated power level requirements, and the key attributes photovoltaic power systems should have to be useful there.

The key attributes for a given mission subset have been listed in relative priority order, with the caveat that the relative importance of any particular system feature for an actual mission depends in a critical way on the outcome of system trade-off studies. Within that constraint, the NASA program attempts to provide both new technology for actual use on future missions, and a sufficient technology database so that mission planners can make such trades with reasonable confidence. The desired system attributes listed for each of the mission subsets guide the technology thrusts of the various elements of the program. At the cell level, for example, the most important technology thrusts. are high efficiency and radiation tolerance. At the blanket and array levels 
the important thrusts are low mass, high. strength, durable blanket and structura 1 components for high performance arrays; concentrator array components and panel development; and total system integration. The latter is important to assure that advances in technology at the various levels will result in net total system benefits that will have a real impact on mission planning and implementation. It is not possible within the confines of this paper to describe the full extent of the NASA photovoltaic R\&T program except to say that it ranges from fundamental investigation of photovoltaic materials and devices to demonstration of array structures (deployment mechanisms, e.g.) and advanced panel power conversion capabilities. Figure 2 11lustrates this approach for the unmanned near-earth and planetary subset. High efficiency, radiation tolerant, lightweight solar cells, when combined with ultralightweight, high strength structural components and advanced techniques for blanket and array assembly, will have a major impact on such spacecraft, and significantly increase their payload and mission capabilities. The possibility exists to nearly double the payload fraction by using advanced photovoltaic technology.

Projections of power system characteristics based on continued use of flat plate silicon solar cell arrays have been used to preclude photovoltaics as a power generation source for large space systems. The primary reason is the physical size of a conventional silicon cell array. It is considered to be excessive, given the unknown capability of today's attitude/orbital position control system technology to handle the large, possibly distributed space systems of the future. From a technology standpoint the assumption is simply not true: Higher efficiency solar cells, such as are emerging from the present NASA program in III-V semiconductors, could reduce the size of solar arrays significantiy. The presumed expense of such cells, although thought to be a prohibitive factor, need not be so. In the early to mid 1970's NASA decided to address the issue of PV arrays for large power systems and sponsored a series of industry studies to identify a suitable technological approach which coupled the promise of high performance (and therefore lower area) with the potential for lower cost (ref. 2). The results of those studies clearly identified the use of concentration at low to moderate levels ( $5 x$ to $200 x$ ) for large solar arrays as the technology of choice. The important point is that a concentrator array can use smaller solar cells (the total semiconductor area is reduced approximately by $2.5 / C R$ at $100 x$, or to about 2.5 percent of total cell area at one sun) to achieve the same output as a flat plate array. With concen. trator cells approaching the chip size of large integrated circuits the possibility exists for substantially lower cell costs. The availability of affordable, higher efficiency, advanced cells will make possible reductions in array area by a factor of two or more at a given power level. Figure 3 illustrates the approach. Its impact is shown by the comparison of PV array size with that projected for a liquid organic rankine solar dynamic system. Full development of this technology will have a substantial payoff for large space systems, not only in terms of total size, but also in simplicity, reliability, and familiarity of use. The paragraphs that follow will highlight some of the current NASA research and technology which addresses the above program requirements and issues.

\section{INDIUM PHOSPHIDE CELL RESEARCH}

Figure 4 shows a plot of calculated ideal efficiency as a function of bandgap in the AMO solar spectrum (ref. 3). The locations of the bandgaps of 
S1, GaAs, and InP are shown on the figure. Reason for the interest shown in GaAs by the space community is self-evident: it has a higher theoretical efficiency than silicon. An important property not depicted by this curve, however, is the efficiency of a solar cell after exposure to the naturally occurring charged particle radiation found in the space environment (primarily trapped electrons and protons, and solar flare protons). Calculations predicting that behavior are difficult to make, with the result that any cell material and design must undergo radiation testing to determine its spaceworthiness. Such testing is usually done in ground based faclilities, since the cost of spacefight testing and verification. is extremely expensive, and opportunities are limited. However, even ground based experiments suffer from some uncertainty because it is not possible to duplicate the particle and energy distribution that may be encountered at varfous orbits and at various times. Only after years of effort has it become possible to refer to an equivalent radiation dose for silicon solar cells using $1 \mathrm{MeV}$ electrons in an accelerator. For example, it is now accepted that the accrued damage in a sllicon solar cell after exposure in an accelerator to a $1 \mathrm{MeV}$ electron.fluence of $3 \times 1014 \mathrm{~cm}-2$ is equivalent to that acquired after 7 years in geosynchronous orbit with a $250 \mu \mathrm{m}$ coverglass on the cell. It is also common practice to quote the behavfor of other cell types after exposure to the same laboratory fluence, so that initial comparisons can be made. The uncertainties caused by this approach can only be resolved by spaceflight testing coupled with extensive cataloging of laboratory irradiation results. With the preceding caveat, figure 5 depicts the projected behavior of InP, GaAs, and silicon cells as a function of orbit altitude. The comparison is made between specific powers (i.e., w/kg,) for the same initial array output before exposure. The difference in BOL specific powers is caused by the reduced array area (and hence reduced balance-of-system mass) needed for higher efficiency solar cells. All array weights are based on an advanced array structure concept (ref. 4), the technology for which is currently being developed in the NASA PV program. The BOL efficiencies are measured numbers for Si and GaAs, and a predicted number for InP (ref. 5). As the figure. shows, a lightweight InP array could have superior performance compared to either of the other two materials. As significantiy, such an InP array will have a specific power in the radiation beits that is better than the best solar array BOL (approximately $35 \mathrm{w} / \mathrm{kg}$ ) that has been flown to date. Actual efficiencies in InP (AMO) are now slightly above 14 percent (ibid). Figure 6 summarizes the situation (ref. 6). Inp cells are in the very early stages of their development. Based on our experience with GaAs and Si, there is little reason to doubt that 20 percent AMO efficiencies can be achieved.

\section{ADVANCED SOLAR CELLS}

The list of advanced solar cell candidates currently under investigation for space use is quite extensive, and cannot be discussed in detall here. A major in-house effort, however, is the development of a dot junction GaAs solar cell. Weizer and Godlewski (ref. 7) have shown that efficiencies above 25 percent AMO are possible at one sun in such a cell, based on material and operating parameters already achleved in laboratory devices. Developing such a cell for use in concentrated sunlight could well result in efficiencies near 28 percent AMO. A key issue to be addressed, however, is the radiation tolerance of such a device, since its successful operation is critically dependent on maintaining diffusion lengths long enough to provide good current collection. A projected design calls for approximately 1 percent coverage by the junction area to achieve high open circutt voltage in the device. If the dots are $1 \mu \mathrm{m}$ 
in diameter, diffusion lengths on the order of $100 \mu \mathrm{m}$ will be required. Such numbers have been observed in very pure, lightly doped material (ref. 8). Also critical to the successful demonstration of this cell is the development of a good passivation technique for the exposed high resistivity GaAs surfaces. Much work remains to be done on this cell before it is a practical reality, but its potential for improving the applicability of photovoltaics for space missions makes it an important element of the program.

Development of a super-high efficiency GaAs cell has another interesting implication. Figure 7 contains plots of the efficiency contours of a two junction tandem solar cell in a two terminal and a four terminal configuration (ref.9). The bottom cell bandgap is the ordinate of each plot, and the top cell bandgap is the abscissa. The calculation is for 100x AM0, and a cell temperature of $80^{\circ} \mathrm{C}$. As with the terrestrial spectrum, the optimum bandgaps are near 1.75 and $1.1 \mathrm{eV}$, and as the figure shows, an ideal efficiency of 35 percent AMO is expected. In this case the top cell must have well above a 20 percent conversion efficiency, with the remainder coming from the $1.1 \mathrm{eV}$ bottom cel1. The figure also makes clear the desirability of using four instead of two terminals: there is a wider range of acceptable bandgaps for the former case. Of interest, however, is the performance that might be achieved by combining a dot junction GaAs concentrator cell with a slightly lower bandgap bottom cell of, e.g., InGaAs. A combination of planer junctions might approach 30 percent efficiency, and output should be enhanced by the dot geometry to something in excess of that. Even assuming that practical efficiencies require discounting the calculations by a few percentage points, efficiencies in the low to mid-thirty percent range could be feasible.

\section{CONCLUDING REMARKS}

$\therefore \quad$ We have reviewed briefly the nature of the requirements that must be addressed for the successful application of photovoltaic power generation in space. The opportunities are plentiful and challenging, and overcoming them should provide significant new capabilities for a variety of future space missions.

\section{REFERENCES}

1. "NASA Space Systems Technology Mode1," 5th Edition, NASA Headquarters, Washington, D.C. (1984).

2. R.E. Patterson, "Study of Multi-kilowatt Solar Arrays for Earth-orbit Applications," (REPT-38172-6001-UE-00, TRW Space Technology Labs; NASA Contract NAS8-34131) NASA CR-170939 (1983).

3. "Solar Cells-0utlook for Improved Efficlency," (NSR-09-012-903, National Research Council) NASA CR-127234 (1972).

4. J. Scott-Monck, "Progress in Developing High-Performance Solar Blankets and Arrays," in Space Photovoltaic Research and Technology, 1982, NASA CP-2256, pp. 201-209 (1982). 
5. I. Weinberg and D.J. Brinker, "Indium Phosphide Solar Cells: Status and Prospects for Use in Space," in Proceedings of the 21 st Intersociety Energy Conversion Engineering Conference, Vol. 3, pp. 1431-1435. American Chemical Society (1986).

6. I. Weinberg, C. Swartz, R:E. Hart and M. Yamaguchi, "Radiation Damage in Proton Irradiated InP Solar Cells, in Fifth European Symposium on Photovoltaic Generators in Space. ESA-SP-267, European Space Agency (1986) (to be published).

7. V.G. Weizer and M.P. Godlewski, "Effect of Solar Cell Junction Geometry on Open-Circuit Voltage," J. App 1. Phys. 57(5), 2292 (1985).

8. R. Nelson, "Measurement of $100 \mu \mathrm{m}$ Minority Carrier Oiffusion Lengths in p-Gallium Arsenide by a New Photoluminescence Method," in Gallium Arsenide and Related Compounds 1978, C.M. Wolfe, ed., pp. 256-262, Institute of Physics, Bristol (1979).

9. J.C.C. Fan and B.J. Palm, "Optimal Design of High Efficiency Single-Junction and Tandem Concentrator Space Cells at $80^{\circ} \mathrm{C}$ and 100 SUNS, "in Space Photovoltaic Research and Technology 1983, NASA CP-2314, pp. 120-127 (1984).

TABLE I

\begin{tabular}{|c|c|c|}
\hline Mission subset & Power level & System attributes \\
\hline $\begin{array}{l}\text { Unmanned Near Earth (LEO, } \\
\text { HEO, GEO) and Planetary } \\
\text { Applications }\end{array}$ & Low to Intermediate & Low Mass, Long Life \\
\hline Space Station & High & $\begin{array}{l}\text { Minimum Area, Low Mass, } \\
\text { Low Cost }\end{array}$ \\
\hline GEO Platform & Intermediate & Long Life, Low Mass \\
\hline $\begin{array}{l}\text { Lunar Base, Manned } \\
\text { Planetary }\end{array}$ & Intermediate to High & $\begin{array}{l}\text { Low Mass Portability } \\
\text { Long Life }\end{array}$ \\
\hline $\begin{array}{l}\text { Electric Propulsion } \\
\text { Orbit Transfer (OTV) }\end{array}$ & High & $\begin{array}{l}\text { Reusability, Minimum } \\
\text { Area, Low Mass }\end{array}$ \\
\hline
\end{tabular}




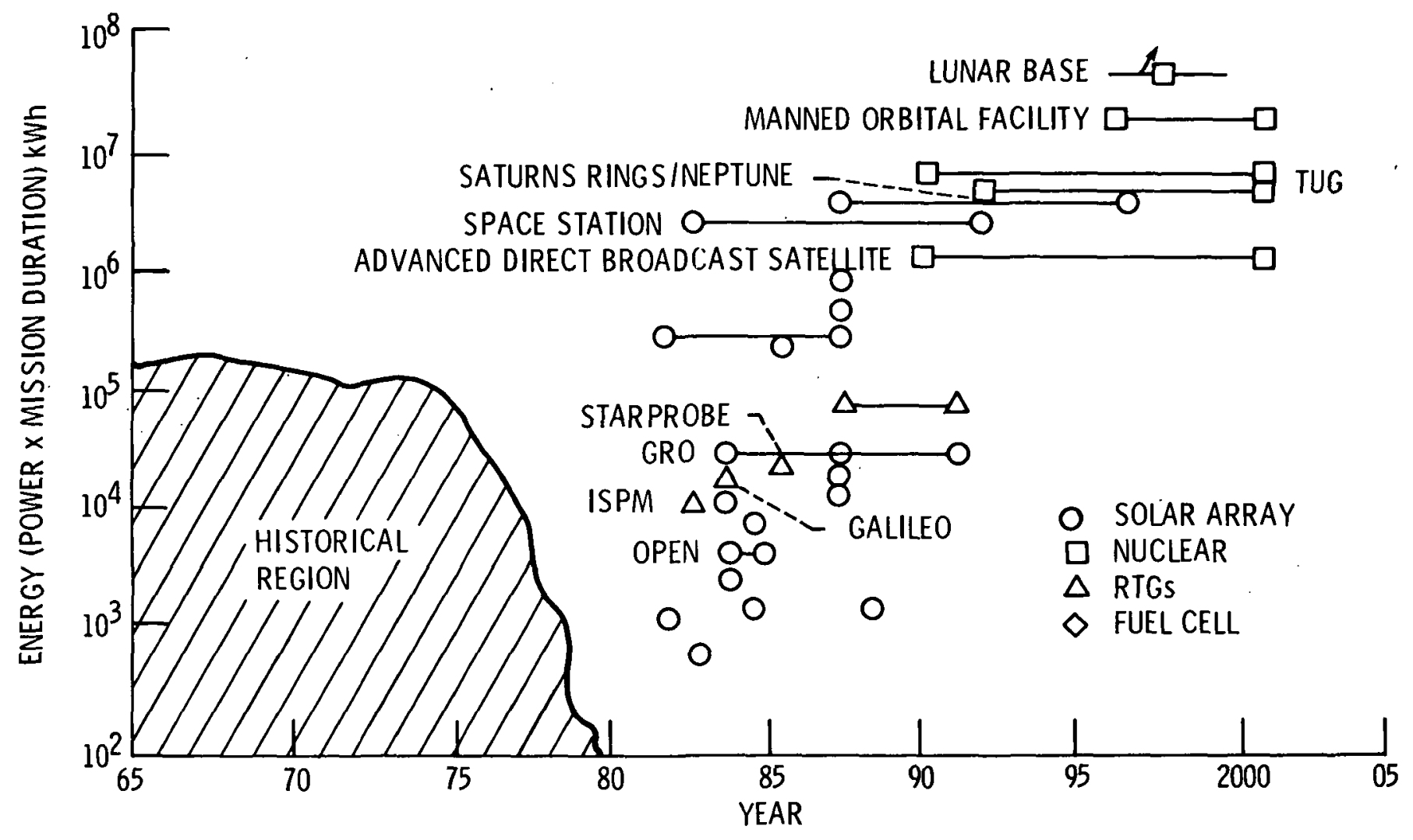

Figure 1. - Future space energy demands. 


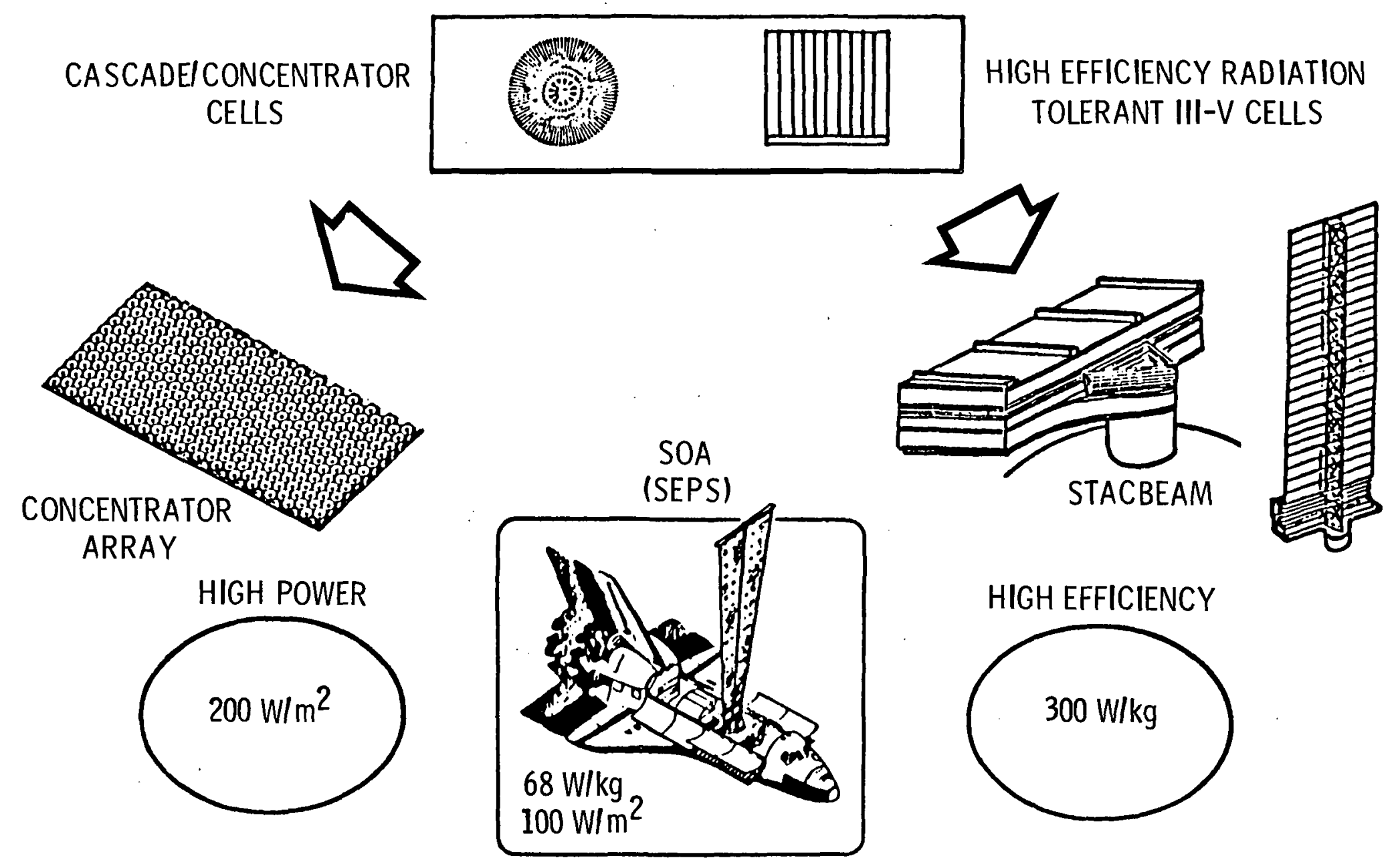

Figure 2. - Photovoltaic Technology. 


\section{THRUSTS}

O HIGH EFFICIENCY. SMALL AREA CELLS

O LIGHTWEIGHT, EFFICIENT OPTICS

O RIGID; DEPLOYABLE, LIGHTWEIGHT ARRAYS

O REDUCED POINTING REQUIREMENTS

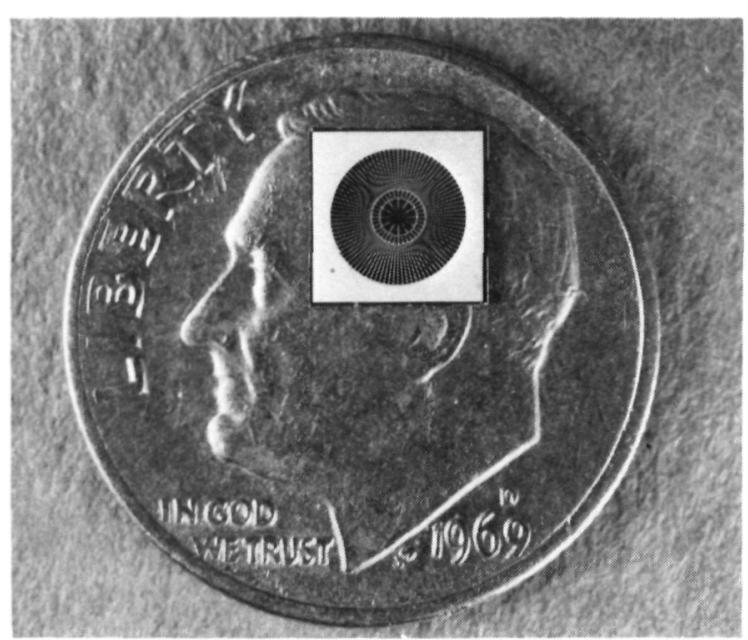

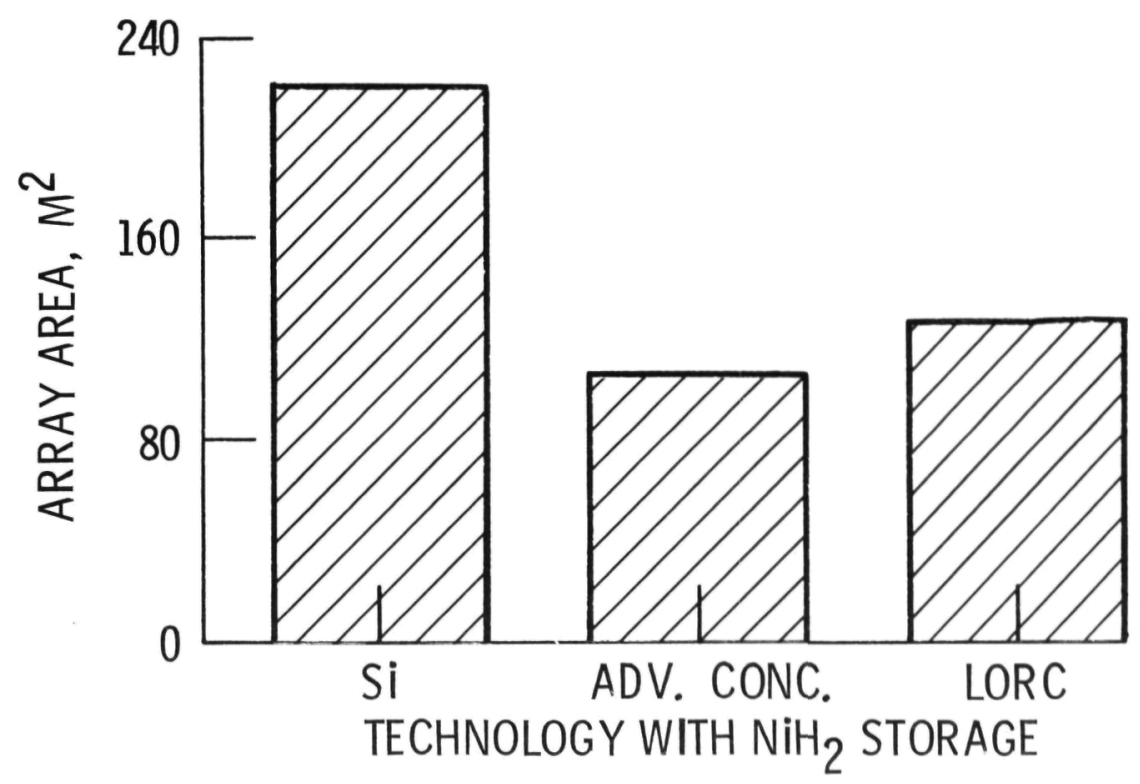

PLANAR Si:

$14 \%$ CELL

ADVANCED CONCENTRATORS:

$>30 \%$ CELL

$>94 \%$ OPTICAL EFFICIENCY

Figure 3. - Concentrator Array Technology. 


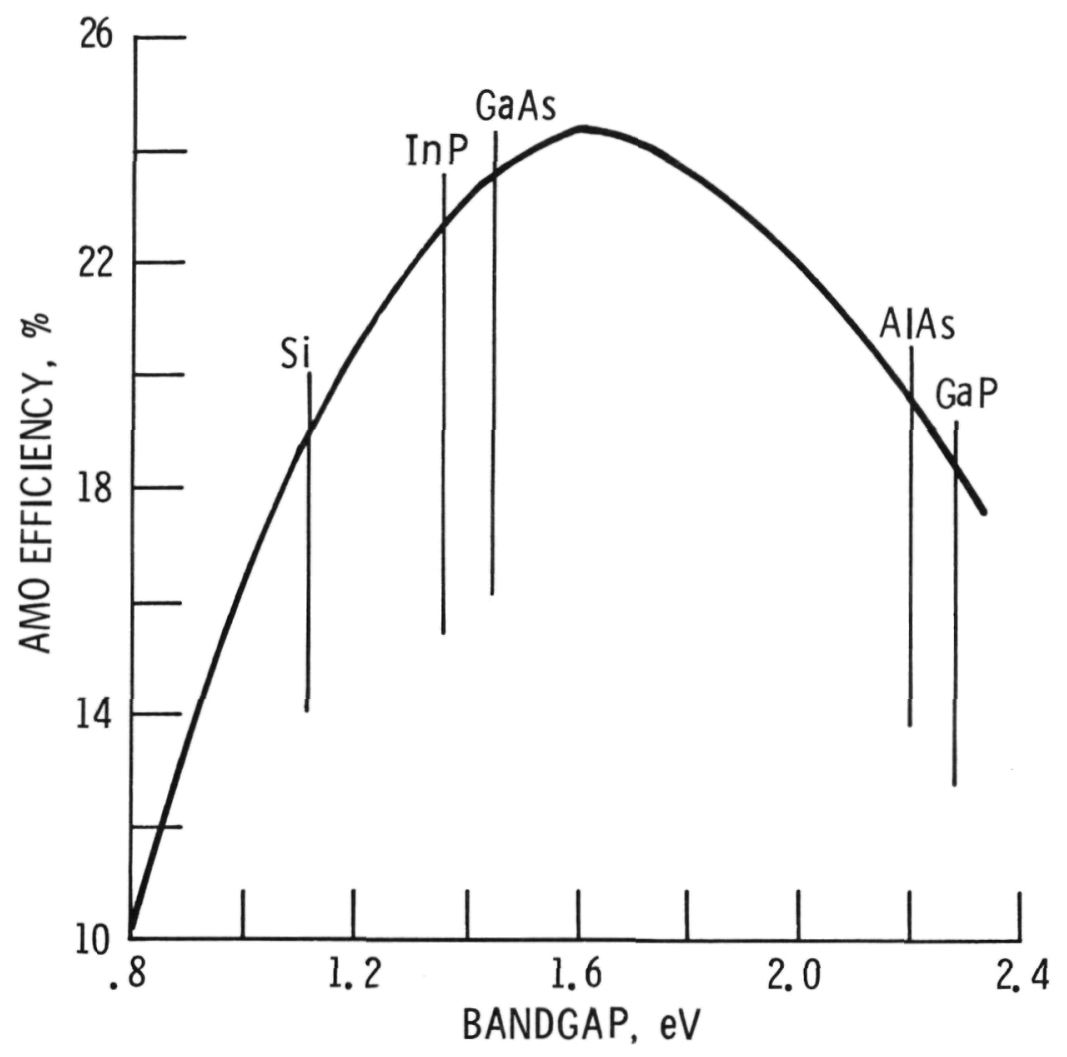

Figure 4. - Efficiency versus bandgap at AMO.

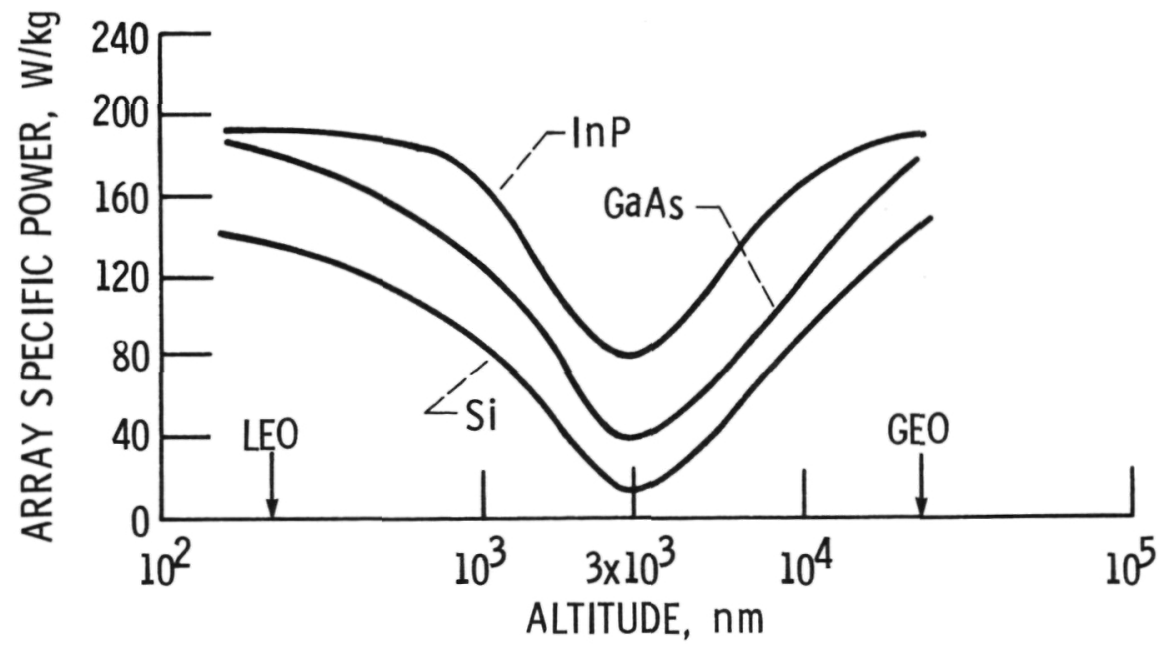

Figure 5. - Comparison of solar array calculated output as a function of orbit altitude, based on $1 \mathrm{MeV}$ electron equivalent fluences. Time in orbit $=7$ years, circular orbit, $30^{\circ}$ inclination, $\mathrm{T}=60^{\circ} \mathrm{C}$. 


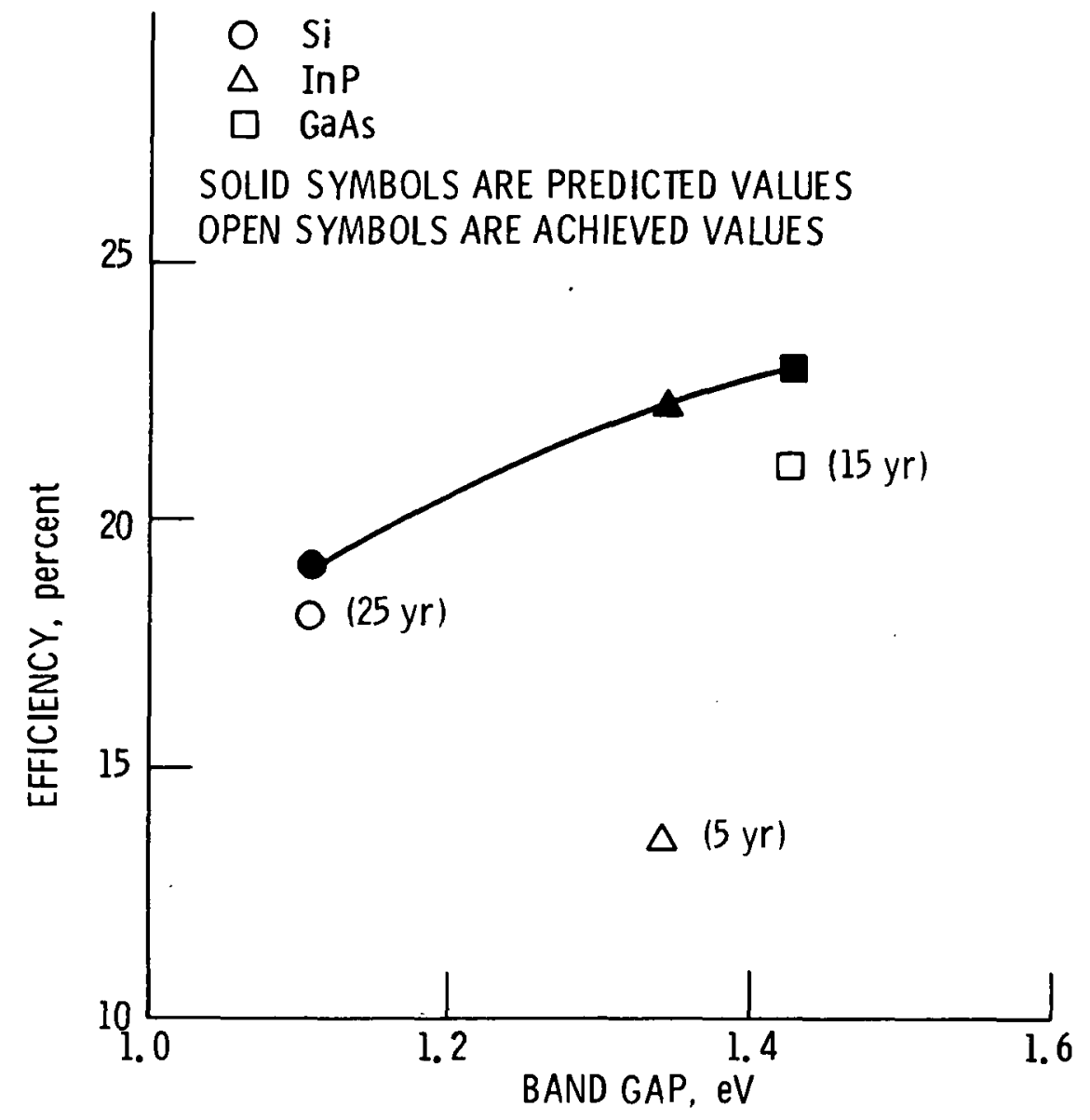

Figure 6. - Predicted and achieved AMO efficiencies. 
TWO-CELL TANDEM FOUR TERMINAL

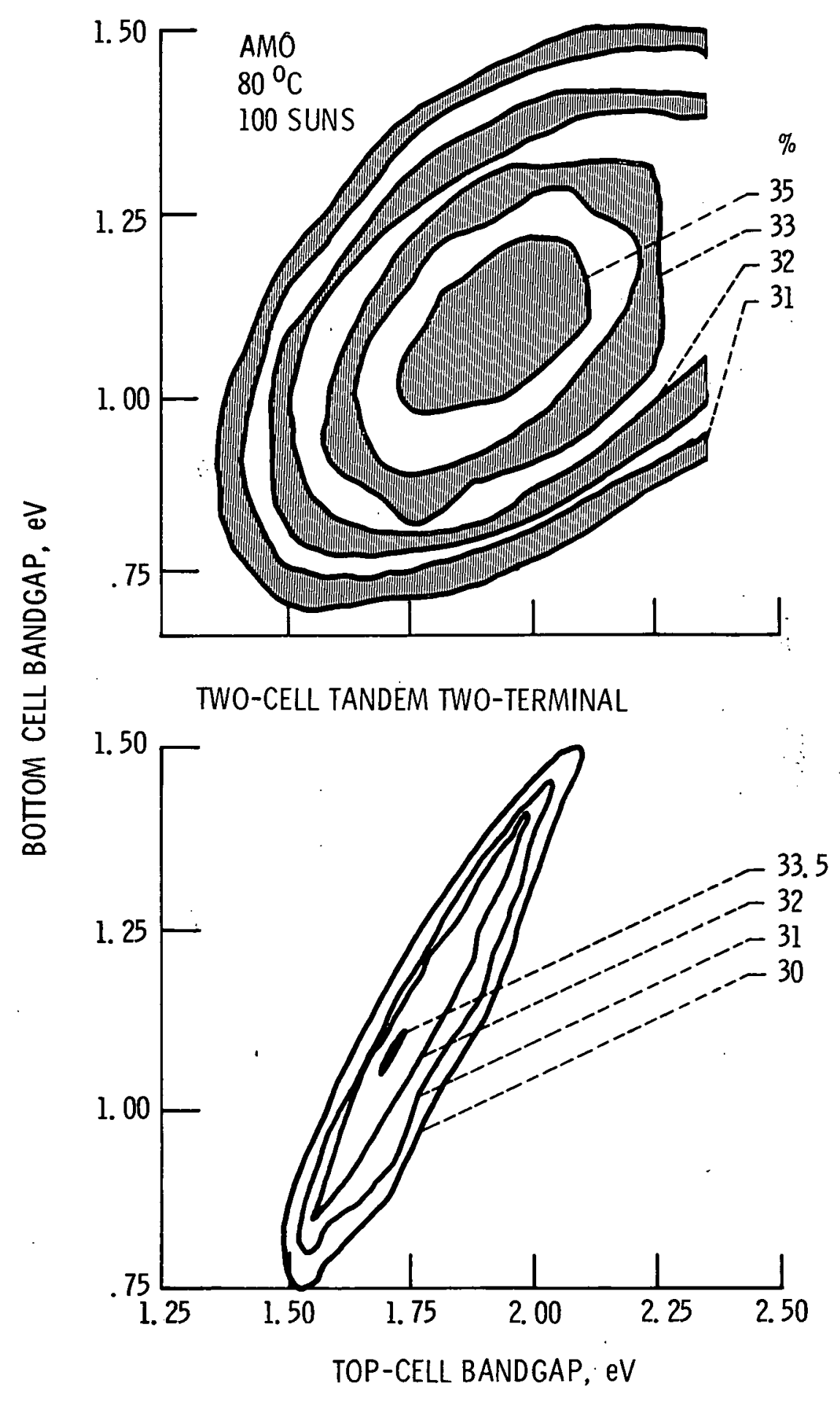

Figure 7. - ISO - efficiency curves. 


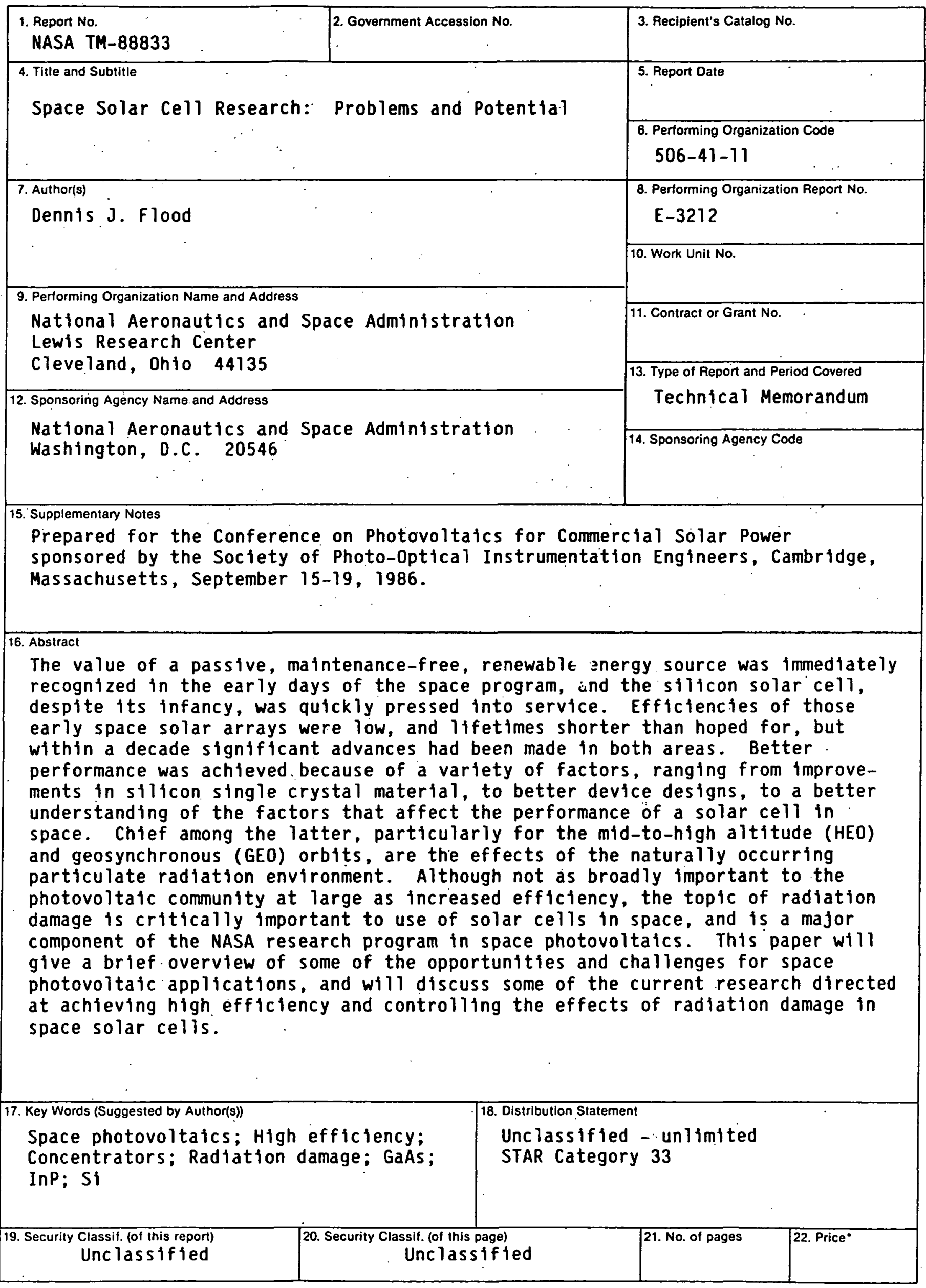


National Aeronautics and

Space Administration

Lewis Research Center

Cleveland. Ohio 44135

Official Business

Penalty for Pitvate Use $\$ \$ 00$
SECOND CLASS MAIL.

ADDRESS CORRECTION REQUESTED

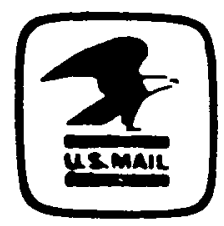

Postage and Fees Paid

National Aeronautics and

Space Administration

NASA-451 